\title{
Psychotherapy between Medicine, Psychoanalysis, and Politics: Concepts, Practices, and Institutions in Germany, c. 1945-1992
}

\section{VOLKER ROELCKE*}

Looking back at almost fifty years of psychotherapy in post-war Germany, Annemarie Dührssen (1916-98), one of the grand old ladies of the discipline, proudly presented a story of success in 1994. In the immediate post-war years, between 1946 and 1950, there were already a considerable number of individuals and groups all over the country active in establishing hospitals or outpatient clinics exclusively devoted to psychosomatic medicine and psychotherapy; in 1950, the first university programme in the subject was set up in Heidelberg; in 1967, psychoanalytically oriented psychotherapy was included in the catalogue of services offered by the statutory health insurance system; and in 1970, psychosomatic medicine and psychotherapy had become obligatory subjects in the curriculum of medical students, resulting in the establishment of chairs in these areas at almost every medical faculty in West Germany. ${ }^{1}$

According to her evaluation, this development was due to the increasing awareness and willingness of psychoanalysts to prove the efficacy of their approach in "scientific" terms, and to the equally increasing awareness among representatives of health policies of the psychological dimension of disease causation and rational disease management. ${ }^{2}$ However, a closer look at the period in question shows that all the high points and achievements listed by Dührssen were the result of complex negotiations between various and shifting groups of physicians, psychologists and politicians, who were heavily dependent on intellectual resources and professional alliances inherited from the first decades of the twentieth century, political attitudes created in public debates following the defeat of Nazi Germany and, finally, financial funds supplied according to political and economic deliberations and in part provided by foreign sources.

In this article, I shall reconstruct and contextualize one of the major "events" among these developments and outline its significance for the broader history of psychotherapy in post-1945 West Germany: the establishment of the department of psychosomatic medicine and psychotherapy at the University of Heidelberg, which was the first academic programme in psychotherapy at a German university. The paper is divided into three

* Prof. Dr. Volker Roelcke, Institut für Geschichte der Medizin, Universität Giessen, Jheringstrasse 6, D-35392 Giessen, Germany.

This is a revised version of a paper presented at the Anglo-Dutch-German workshop on 'Social Psychiatry and Ambulant Care in the $20^{\text {th }}$ Century', in London, 4-6 July 2002. I wish to thank Michael Neve, Harry Oosterhuis, Caroline Welsh, and the participants of the workshop for helpful criticism.

\footnotetext{
${ }^{1}$ Annemarie Dührssen, Ein Jahrhundert Psychoanalytische Bewegung in Deutschland, Göttingen, 1994, pp. 199-236. A short biography of Dührssen appears in the obituary by Ulrich Rüger, 'Annemarie Dührssen (1916-1998)', Nervenarzt, 1999, 70: 482-3.

${ }^{2}$ Dührssen, op. cit., note 1 above, pp. 223-36.
} 


\section{Volker Roelcke}

parts: the first gives an outline of early initiatives towards an institutionalization of psychotherapy and the resources used for these activities; the second part focuses on the establishment of the Heidelberg programme in the late 1940s as a case of conflict involving professional interests and struggles over appropriate answers to the activities of the "doctors of infamy" in the Third Reich; and the third gives an overview of the further developments and features of psychotherapy in West Germany since the early 1950s.

\section{Individual Initiatives, Shared Resources: The First Post-War Institutions}

A browse through contemporary medical journals and hospital registers reveals that a considerable number of in- or outpatient institutions specifically employing psychotherapeutic approaches were created in the late 1940s.

In Lübeck, Friedrich Curtius established a ward specifically devoted to psychosomatics and psychotherapy within the public hospital for internal medicine (1946); in BerlinGrunewald Heinz Wiegmann opened a private "hospital for psychogenic disorders" (Klinik für psychogene Störungen) in $1948{ }^{3}$ in Rasemühle near Göttingen (Lower Saxony), the state psychiatric asylum was complemented by a department for psychotherapy headed by Gottfried Kühnel (1948); at the department of internal medicine of Munich University, Walter Seitz opened a psychosomatic out-patient clinic (1949); the well-known sanatorium Bühler Höhe in the Black Forest shifted its focus to psychotherapy when the psychiatrist Immo von Hattingberg, associated with the University of Freiburg, was appointed director in $1949 ;{ }^{4}$ and in 1950 , Arthur Jores established a private psychosomatic-psychotherapeutic inpatient hospital as a complementary service to the department of internal medicine at the University of Hamburg which was also directed by him. ${ }^{5}$

Apparently, there was something like a boom in psychotherapy in these years. What were the general preconditions and what the local specificities for this? Regarding the general conditions, three main factors can be identified: intellectual resources drawing on the idea of a "holistic" approach to disease and therapy derived from an intensive debate on the "crisis of medicine" in the late Weimar republic; a long tradition of conflict and indeed rift between orthodox, institutionalized psychiatry and psychoanalysis; and the contemporary acknowledgement that the atrocities of Nazi medicine were the result of a one-sided and reductionist view of human beings.

The "crisis of medicine" was a widely debated issue from the mid-1920s. Physicians from all medical specialities, including surgeons like Erwin Liek and Ferdinand Sauerbruch, professors of internal medicine like Theodor Brugsch and Wilhelm His, gynaecologists like Bernhard Aschner, and bacteriologists like Hans Much joined in

\footnotetext{
${ }^{3}$ Heinz Wiegmann, 'Psychotherapie stationär', Medizinische Klinik, 1949, 44: 304; idem, 'Die Klinik für psychogene Störungen in Berlin-Grunewald', Psyche, 1950, 5: 389.

${ }^{4}$ On the establishment of a psychotherapeutic programme within the Department of Internal Medicine of Freiburg University, see Lucie Fischer, 'Die Geschichte der Abteilung für klinische Psychotherapie innerer Krankheiten der
}

\author{
Universität Freiburg', unpublished Med. Diss, \\ Freiburg 1995. \\ ${ }^{5}$ Arthur Jores, 'Erfahrungen mit der \\ Psychotherapie im Rahmen einer medizinischen \\ Klinik', Münchener medizinische Wochenschrift, 1953, \\ 95: 1152-5; H Baerwolf, 'Grundlagen und \\ Arbeitsweise einer Psychosomatischen Klinik’, \\ Zeitschrift für Psychosomatische Medizin und \\ Psychoanalyse, 1957/58, 4: 233-43.
}




\section{Psychotherapy in Germany, c. 1945-1992}

this discussion. ${ }^{6}$ They claimed that a materialist or even mechanistic view of the patient predominated, with consequent loss of a "holistic" perspective integrating the biological with the psychological dimension of the sick person's suffering. The perceived modern ideal of the Mediziner, a physician researcher focusing on the natural sciences, was contrasted with the supposed previous reality of the Arzt, a family doctor interested in all dimensions of the life of his patient. Hippocrates or Paracelsus were named as the foremost examples of this ideal type of physician. ${ }^{7}$

This diagnosis of contemporary medicine led, however, to diverging conclusions: one tradition aimed at the reconstitution of "organic", or "biological" unities, the search for hidden or forgotten healing forces in nature, and consequently turned away from scientific medicine to look for alternatives, for example, in naturopathy or homeopathy. This strand of ideas was in several ways compatible with already established movements and institutions of alternative medicine, and met with considerable sympathy among the broader public before and after 1933, and also among leading Nazi politicians. One of the reasons for this was that it also resonated with ideas of a healthy national organism (Volkskörper) which were central to racial hygiene and the social and health policy of the Nazi regime. As a matter of fact, during the first years of the new regime, all these movements received strong support from leading Nazi medical functionaries, and the newly created organization called Reichsarbeitsgemeinschaft Neue Deutsche Heilkunde (Reich's Working Group for New German Medicine), which attempted to integrate all these reform movementsincluding the first Association of Medical Psychotherapists (Allgemeine Ärztliche Gesellschaft für Psychotherapie)—was directly subordinated to the leader of the Reich's physicians, Gerhard Wagner. ${ }^{8}$

A related, but more specific answer to the supposed "crisis" was the boost in the institutionalization of psychotherapy. The inauguration of the above mentioned Association of Medical Psychotherapists (founded in 1926 and mainly consisting of representatives of the somatic disciplines), ${ }^{9}$ the launch of journals devoted partly or wholly to matters of psychotherapy, ${ }^{10}$ and the establishment of a few psychoanalytically inspired clinics and sanatoria occurred in the late 1920s. All these developments may be understood as a reaction

\footnotetext{
${ }^{6}$ See Eva-Maria Klasen, 'Die Diskussion über eine "Krise" der Medizin in Deutschland zwischen 1925 und 1935', MD dissertation, Mainz University, 1984; Hans-Peter Schmiedebach, 'Der wahre Arzt und das Wunder der Heilkunde. Erwin Lieks ärztlich-heilkundliche Ganzheitsideen', Argument Sonderband, 1989, 162: 33-52; Detlef Bothe, Neue Deutsche Heilkunde 1933-1945. Dargestellt anhand der Zeitschrift "Hippokrates" und der Entwicklung der volksheilkundlichen Laienbewegung, Husum, Matthiesen 1991, pp. 16-37; Carsten Timmermann, 'Weimar medical culture', unpublished $\mathrm{PhD}$ thesis, University of Manchester, 1999.

${ }^{7}$ Bothe, op. cit., note 6 above; Carsten Timmermann, 'A model for the new physician: Hippocrates in interwar Germany', in D Cantor (ed.), Reinventing Hippocrates, Aldershot, Ashgate, 2002, pp. 302-24.
}

\footnotetext{
${ }^{8}$ Bothe, op. cit., note 6 above; Geoffrey Cocks, Psychotherapy in the Third Reich: the Goring Institute, New York and Oxford, Oxford University Press 1985; Uwe Zeller, Psychotherapie in der Weimarer Zeit: Die Gründung der Allgemeinen Ärtlichen Gesellschaft für Psychotherapie (Ä̈GP), Tübingen, Medienverlag Köhler, 2001.

${ }^{9}$ Wladimir Eliasberg, Bericht über den I. allgemeinen ärztlichen Kongress für Psychotherapie in Baden-Baden, Halle, 1927.

${ }^{10}$ For example, the Allgemeine ärztliche Zeitschrift für Psychotherapie und psychische Hygiene, einschliesslich der klinischen und sozialen Grenzgebiete, vol. 1, 1928, from vol. 3, 1930 onwards renamed Zentralblatt für Psychotherapie; or Der Nervenarzt, vol. 1, 1928, which in its inaugurating editorial formulated the programme to integrate psychotherapeutic and psychoanalytical approaches in the debates of psychiatrists and Nervenärzte.
} 


\section{Volker Roelcke}

to a critique which realized that the subjectivity of the patient had disappeared from the agenda of mainstream, particularly academic, medicine. ${ }^{11}$ The interest in psychological factors of disease causation and symptom formation also resulted from a growing concern with the impact of war neuroses. The apparent increase in the number of such neurotic disabilities were seen as causing considerable challenges to the insurance system and to the national economy as a whole. ${ }^{12}$

The initiatives to institutionalize psychotherapy experienced specific modifications during the Nazi period, caused in particular by the forced migration of Jewish psychoanalysts after 1933, but also by the increasing impact of various strands of "holistic" and other forms of psychotherapy. From 1936 onwards, there existed a central German Institute for Psychotherapy in Berlin which attempted to integrate different schools (Freudian, Jungian, Adlerian), and whose representatives served — among other purposes—as expert advisers for the air force and the army. ${ }^{13}$

The diagnostic and therapeutic repertoire, professional networks and institutional structures created in these decades before 1945 represented resources which were used by the protagonists of post-1945 psychotherapy.

A second factor contributing to the specific boom in psychotherapy after the Second World War, in particular in the form of psychosomatic medicine, was the continuing conflict between established psychiatry and psychoanalysis in Germany. The academic establishment of psychiatry in the decades around 1900 was in a way based on an adaptation of disease models, research strategies and approaches to preventive or therapeutic intervention which was oriented on the somatic disciplines, on experimental psychology, and ultimately the natural sciences. ${ }^{14}$ The success of this direction of psychiatry appeared certain with the foundation in Munich in 1917 of the German Institute for Psychiatric Research, which a few years later became part of the prestigious Kaiser-Wilhelm Society and served as a model for, among others, the Maudsley Hospital (founded in London in the 1920s) and the related Institute of Psychiatry. In this context of professional politics in the early decades of the century, German psychiatrists denounced psychoanalysis as speculative and unscientific, and widely held the view that any alliance with its ideas or exponents might endanger psychiatry's newly achieved status as a "real" medical discipline. As a result, protagonists of psychiatry fought heavy rhetorical battles with psychoanalysis, ${ }^{15}$ and

\footnotetext{
${ }^{11}$ Christina Schröder, Der Fachstreit um das Seelenheil. Psychotherapiegeschichte zwischen 1880 und 1932, Frankfurt/ Main, Peter Lang, 1995; Volker Roelcke, 'Die Entwicklung der Psychiatrie zwischen 1880 und 1932: Theoriebildung, Institutionen, Interaktionen mit zeitgenössischer Wissenschafts-und Sozialpolitik', in R vom Bruch, B Kaderas (eds), Wissenschaften und Wissenschaftspolitik. Formationen, Brüche und Kontinuitäten im Deutschland des 20. Jahrhunderts, Stuttgart, Franz Steiner, 2002, pp. 109-24.

${ }^{12}$ Doris Kaufmann, 'Science as cultural practice: psychiatry in the First World War and Weimar Germany', J. Contemp. Hist., 1999, 34: 125-44; Paul Lerner, Hysterical men: war, psychiatry, and the politics of trauma in Germany, 1890-1930, Ithaca and London, Cornell University Press, 2003.
}

\footnotetext{
${ }^{13}$ Cocks, op. cit., note 8 above; Regine Lockot, Erinnern und Durcharbeiten. Zur Geschichte der Psychoanalyse und Psychotherapie im Nationalsozialismus, Frankfurt/Main, Fischer, 1985.

${ }^{14}$ See Roelcke, op. cit., note 11 above; and Eric J Engstrom, Clinical psychiatry in imperial Germany: a history of psychiatric practice, Ithaca and London, Cornell University Press 2003.

${ }^{15}$ See, for example, Alfred Hoche, 'Über den Wert der Psychoanalyse', Archiv für Psychiatrie und Nervenkrankheiten, 1913, 51: 1055-79; Ernst

Kretschmer, 'Zur Kritik des Unbewussten', Zeitschrift für die gesamte Neurologie und Psychiatrie, 1919, 46: 369-87; Oswald Bumke, Die Psychoanalyse. Eine Kritik, Berlin, 1931.
} 
almost all available resources were directed to research into the somatic aspects of mental disorder, in particular neuropathology and genetics. ${ }^{16}$

Psychiatric genetics in particular was inextricably intertwined with eugenics. The first institution exclusively devoted to research in the inheritance of psychiatric disorders was the department of genealogy and demography at the German Psychiatric Research Institute in Munich. From its foundation in 1917 until the end of the Second World War in 1945, it was directed by Ernst Rüdin, one of the protagonists of the racial hygiene movement in Germany. Judged in scientific terms, and by colleagues from Britain and the US, the research undertaken by Rüdin and his co-operators was evaluated as outstanding in $1933 / 34$, and as remarkable even in the post-1945 period. The aim of re-structuring society according to the laws of biology was the guiding principle motivating all of Rüdin's research and political activities. He and most of his staff were in one way or another involved in Nazi mental health policy, including active support of the systematic patient killings ("euthanasia"), and in research aimed at finding scientifically valid criteria for distinguishing between those worthy for procreation, or indeed worthy to live, and those supposedly unworthy. ${ }^{17}$

In the immediate post-war era, there existed some awareness about the scientific underpinnings of the atrocities of Nazi medicine and an acknowledgement that it had to do with a one-sided and reductionist view of human beings, associated with specific value judgements linked to prioritizing the health of the collective "folk body" (Volkskörper), or race. The neglect of the subjectivity of the individual patient appeared to be the common denominator for the features of medicine and health policies in the previous decade: a purely biological-somatic approach to health and disease as prevalent in the dominant tradition of German psychiatry along with the radical pursuit of eugenic goals scientifically underpinned by genetics and the broader Nazi social and health policy that clearly subordinated individual wellbeing to that of the nation. ${ }^{18}$

\section{The Department of Psychosomatic Medicine at Heidelberg University}

In this situation, a new focus on psychotherapy as the most adequate primary intervention for mental disorders and even a broader psychoanalytically inspired psychosomatic approach to bodily dysfunctions appeared to be plausible answers to the challenges facing those responsible for the policies and practices in mental health care. The case of the new psychotherapy programme at the University of Heidelberg - the first such programme at a

\footnotetext{
${ }^{16}$ However, in the early and mid-1920s, there existed also a certain interest in alternative intellectual approaches to theoretical and practical challenges in psychiatry, as is testified by the use of concepts from contemporary philosophy (for example, Husserl, Heidegger, Scheler), anthropology (Levy-Bruhl), psychology, and the American Mental Hygiene Movement; the emergence of the movements/ traditions of anthropological psychiatry, and psychische Hygiene is an expression of such creative conceptual imports.

${ }^{17}$ Volker Roelcke, 'Programm und Praxis der psychiatrischen Genetik an der Deutschen
}

Forschungsanstalt für Psychiatrie unter Ernst Rüdin', Medizinhistorisches Journal, 2002, 37: 21-55.

${ }^{18}$ See, for example, the "diagnoses" on the state of German medicine, and psychiatry by Werner Leibbrand, 'Voraussetzungen und Folgen der sogenannten "Euthanasie", , in idem (ed.), Um die Menschenrechte der Geisteskranken, Nürnberg, 1946; Dolf Sternberger, 'Dokumente zu den Geisteskrankenmorden', Die Wandlung, 1947, 2: 160-74, 251-67; Viktor v. Weizsäcker, “"Euthanasie” und Menschenversuche', Psyche, 1947/ 48, 1: 68-102. 


\section{Volker Roelcke}

German university-is paradigmatic for the contemporary concerns, debates, and professional strategies. The conflicts surrounding the establishment of this programme exemplify the impact of already existing intellectual and organizational resources, the various political interests heavily linked to Germany's past, to professional interests, and finally also to specific local initiatives. ${ }^{19}$

Before turning to the origins of the Heidelberg department of psychosomatic medicine, I shall briefly sketch the situation of Heidelberg University immediately after the war. ${ }^{20}$ When the American army moved into Heidelberg on 30 March 1945, the university was closed, as were all other universities in the American occupied zone. The military government planned to establish democratic structures in all areas of public life and, parallel to that, to put in charge responsible individuals with political beliefs and consciousness different from those which had prevailed during the preceding era. This general policy of "de-nazification" also implied that institutions of education and research had to be thoroughly scrutinized and cleared of former party and state functionaries. Originally, the time span envisaged for a careful selection of the new academic staff was about two years. However, there was a group within the military government that wanted simply to get things going again, and their pragmatism served the interests of most of the previous teachers at the university. The leading figure amongst them was Karl-Heinrich Bauer, professor of surgery since 1943, who was determined to ensure a quick re-opening of the university. For Bauer, the universities, together with the churches, were the only "still intact organizations for rebuilding a new leading class". ${ }^{21}$ In his speeches and publications of the immediate postwar period there is not a single comment on the dubious activities of faculty members during the Nazi era. ${ }^{22}$ Likewise, he had no sympathy for the reform plans of the military government. By a series of clever faits accomplis, Bauer was able to revive the governing bodies of the university and then to obtain official American approval for what he had done. Just a few months after the end of the war, he was elected the first Rektor, that is head of the re-opened university.

\footnotetext{
${ }^{19}$ A first, less detailed and contextualized accoun of this case is given in Volker Roelcke, 'Die Zähmung der Psychoanalyse durch öffentliche Institutionen.

Zur Gründungsgeschichte der Heidelberger

Psychosomatischen Klinik', Psychoanalyse im Widerspruch 1991, 6: 13-26; and in idem,

'Psychosomatic medicine in post-war Germany: the domestication of psychoanalysis by public institutions', in L de Goei, J Vijselaar (eds), Proceedings of the 1st European Congress on the History of Psychiatry and Mental Health Care, Rotterdam, Erasmus Publishing, 1993, pp. 51-8; a further account, based on the same sources, tends to overstate and psychologize the conflict between two of the protagonists (A Mitscherlich and V von Weizsäcker): Thomas Henkelmann, 'Zur Geschichte der Psychosomatik in Heidelberg. V. v. Weizsäcker und A. Mitscherlich als Klinikgründer', Psychotherapie, Psychosomatik, medizinische Psychologie, 1992, 42: $175-86$.

${ }^{20}$ On the following, see James F Tent, Mission on the Rhine: reeducation and denazification in
}

American-occupied Germany, University of Chicago Press, 1982; Renato de Rosa, 'Politische Akzente im Leben eines Philosophen. Karl Jaspers in Heidelberg, 1901-1946. Nachwort', in Karl Jaspers, Erneuerung der Universität. Schriften und Reden 1945/ 46, Heidelberg, Lambert Schneider, 1986, pp. 301-423; and Steven Remy, The Heidelberg myth: Nazification and denazification of a German university, Cambridge, MA, Harvard University Press, 2002, chs. 4 and 5.

${ }^{21}$ Quoted in Eike Wolgast, Die Universität Heidelberg 1386-1986, Heidelberg and Berlin, Springer, 1986, p. 169.

${ }^{22}$ Among them were Ernst Rodenwaldt, head of the department of hygiene, a leading racial hygienist, and Carl Schneider, professor of psychiatry, who was involved in the programme of systematic patient killings ("euthanasia"); see Remy, op. cit., note 20 above; and Volker Roelcke, Gerrit Hohendorf, Maike Rotzoll, "Psychiatric research and "euthanasia": the case of the psychiatric department at the University of Heidelberg, 1941-1945', Hist. Psychiatry, 1994, 5: 517-32. 


\section{Psychotherapy in Germany, c. 1945-1992}

Bauer's guiding principle in filling vacant chairs was the following: "We incriminate no one, but we exonerate everyone where it is tenable". ${ }^{23} \mathrm{He}$ had to apply this principle first of all in the medical faculty, since 69 per cent of its members had been found to be connected to one of the Nazi party organizations (as compared to about one third of the faculty of law, and 29 per cent of the faculty of theology). ${ }^{24}$ Nevertheless, Bauer succeeded in partially reopening the medical faculty by August 1945 and the other faculties followed during the winter of that year. ${ }^{25}$

At the same time, another more thoroughly investigative faction within the American military government revealed more and more details about the past of a number of professors who had already been reappointed to their previous chairs. Among the incriminated persons was Bauer himself (due to his involvement in the eugenically motivated practice of enforced sterilization), as well as his deputy and personal friend Fritz Ernst, professor of modern history. ${ }^{26}$ Thus Bauer, the seniors of the university and of the medical school came under increasing pressure to justify their haste in reopening the university, while concealing details of their past activities. It therefore conformed well with the interests of Bauer and many others when the pragmatic American university officer Earl Crum, also a personal friend of Bauer and Ernst, initiated a "De-nazification Committee". In contrast to the group led by the intelligence officer Daniel Penham, which advocated a rigorous purge on security grounds, Major Crum was perfectly satisfied to leave the handling of affairs to the representatives of the university, and so Bauer was able to exploit the rift within the American authorities for his own ends. ${ }^{27}$ The committee had not-as its name may suggest— the purpose of critically evaluating professors according to the needs of the new, democratic orientation of educational institutions. Rather, it was intended to remove obstacles for the rebuilding of the university by re-evaluating the dismissal of those members of the academic staff incriminated during the first round of the de-nazification process.

This was the situation during the 1945/46 winter semester, shortly before Alexander Mitscherlich presented to the medical faculty a proposal for the establishment of an institute of psychotherapy at the university. Mitscherlich (1908-82) is mainly known as one of the official German observers of the Nuremberg medical trial (December 1946 until August 1947) of Nazi physicians accused of medical atrocities, and - together with Fred Mielkeas editor of the tribunal's proceedings. ${ }^{28}$ For the purpose of the present paper, some further features of his career are relevant. As a medical student and member of an opposition group, Mitscherlich had been imprisoned for a few months in 1937/38. After his conditional

\footnotetext{
${ }^{23}$ Quoted in de Rosa, op. cit., note 20 above, p. 372; see also Remy, op. cit., note 20 above, p. 150.

${ }^{24}$ Tent, op. cit., note 20 above, pp. 58-66; Remy, op. cit., note 20 above, found 54 per cent of all medical faculty members incriminated.

${ }^{25}$ Remy, op. cit., note 20 above, pp. 139-41.

${ }^{26}$ See de Rosa, op. cit., note 20 above, pp. 400-16; Bernhard Laufs, 'Vom Umgang der Medizin mit ihrer Geschichte', in G Hohendorf, A Magull-Seltenreich (eds), Von der Heilkunde zur Massentötung. Medizin im Nationalsozialismus, Heidelberg, Wunderhorn 1990, pp. 233-53.

${ }^{27}$ Remy, op. cit., note 20 above, pp. 160-76.
}

\footnotetext{
${ }^{28}$ A first, but in many respects unsatisfying, biography of Mitscherlich is given by Hans-Martin Lohmann, Alexander Mitscherlich, Reinbek bei Hamburg, Rowohlt, 1987; for a more recent account, see Thomas Müller and Désirée Ricken, 'Alexander Mitscherlich's "politische Psychoanalyse", seine Beziehungen zur Humanmedizin und die Wahrnehmung der bundesdeutschen Öffentlichkeit', Tel Aviver Jahrbuch für deutsche Geschichte, 2004, 32: 219-57. The first edition of the trial documentation was published as Alexander Mitscherlich, Fred Mielke (eds), Diktat der Menschenverachtung, Heidelberg, Lambert Schneider, 1947; English version: Alexander
} 


\section{Volker Roelcke}

release on probation, he was able to complete his medical training at the University of Heidelberg where the neurologist Victor von Weizsäcker was his mentor. Weizsäcker followed the tradition of "anthropological medicine", which attempted to integrate philosophical reflections on the nature of man, and the meaning of human suffering, with psychophysiological studies and clinical practice. ${ }^{29}$ In 1941, Mitscherlich was appointed junior doctor at the department directed by Weizsäcker. When Weizsäcker was appointed to the chair of neurology in Breslau in mid-1941, Mitscherlich stayed in Heidelberg to pursue his training in neurology.

After the end of the war, Mitscherlich served for a few weeks as minister of public health affairs in the American zone "Saar-Pfalz-Rheinhessen" in South-Western Germany. When the Heidelberg medical faculty was reopened, he returned to the university where, in March 1946, he received the academic degree of "Privatdozent" in neurology, implying his eligibility for a full professorship in this subject. By that time, Mitscherlich had addressed in many ways and before many different audiences the causes and consequences of National Socialism. He argued that historical, political and philosophical analyses, as well as psychoanalytical considerations, should be brought together to establish new forms of social life and also a reform of medicine. ${ }^{30}$ The type of medical practice characteristic of the late stages of the Nazi era, which in his view was narrowly focused on the natural sciences and no longer limited by legal or ethical considerations, had led to excesses and atrocities not only in the field of medicine, but also in the broader field of health and social policy. The systematic reflection on these developments was-according to Mitscherlich-a central task for the practice of medicine in the future, and for every citizen. These considerations also went into a publication which proposed a philosophical-anthropological foundation of psychotherapy and a psychotherapeutic foundation of medicine in general. The outline of this analysis had already been written in the last months of the war and the revised book was published in $1946 .^{31}$

In close connection with this book, Mitscherlich wrote a 'Memorandum on the establishment of an institute for psychotherapy' at the University, which he presented to the dean of the medical faculty in May $1946 .{ }^{32}$ In the introduction, Mitscherlich expounded on the need

\footnotetext{
Mitscherlich, Fred Mielke (eds), Doctors of infamy: the story of the Nazi medical crimes, New York, Henry Schuman, 1949; the context of the Nuremberg medical trial, and Mitscherlich's role are reconstructed in Paul J Weindling, Nazi medicine and the Nuremberg trials, Houndmills and New York, Palgrave Macmillan, 2004.

${ }^{29}$ On Weizsäcker and the Heidelberg school of anthropologische Medizin, see Wolfgang Jacob, 'Medizinische Anthropologie: Krehl, Siebeck und von Weizsäcker', in Wilhelm Doerr, et al. (eds), Semper Apertus. 600 Jahre Ruprecht-Karls-Universität Heidelberg, Berlin and Heidelberg, Julius Springer, 1986, vol. 4, pp. 126-64; and the collection of papers in Udo Benzenhöfer (ed.), Anthropologische Medizin und Sozialmedizin im Werk Viktor von Weizsäckers,

Frankfurt/ Main, Peter Lang, 1994.

${ }^{30}$ See, for example, Alexander Mitscherlich, 'Geschichtsschreibung und Psychoanalyse.

Bemerkungen zum Nürnberger Prozess', Schweizer
}

Annalen, 1945, 11: 604-13; repr. in Alexander Mitscherlich, Gesammelte Schriften, vol. 7, Frankfurt, Suhrkamp, 1983, pp. 66-77.

${ }^{31}$ Alexander Mitscherlich, Freiheit und Unfreiheit in der Krankheit, Hamburg, Claasen \& Goverts, 1946.

${ }^{32}$ A first draft, undated, but apparently written before 17 Nov. 1945 is held in the Alexander Mitscherlich papers (Alexander Mitscherlich Archiv, hereafter AMA), Stadt- und Universitätsbibliothek Frankfurt/ Main, rep. II a 1; the version of 3 May 1946 submitted to the Heidelberg dean is located ibid.; a further version of the Memorandum dated 6 March 1946 is located in the Universitätsarchiv Heidelberg (hereafter UA HD), Personalakte Mitscherlich (PA Mit.). An analysis of this memorandum is given in A Krovoza, F Schneider, 'Psychoanalyse in Berlin und Heidelberg nach 1945', in H Bareuther, H J Busch, et al. (eds), Forschen und Heilen. Auf dem Weg zu einer psychoanalytischen Hochschule, Frankfurt/ Main, Suhrkamp, 1989, pp. 237-62. 


\section{Psychotherapy in Germany, c. 1945-1992}

to approach the suffering human being through the patient's biography and subjective experiences, in addition to the somatic dimension. He argued that all stages of the disease process, from aetiology, through pathogenesis, manifestation of symptoms and course of the disorder could only be fully and comprehensively understood if this subjective and biographical dimension of the patient was taken into consideration and that this was essential for all diseases, psychological or somatic.

Having explained the need for this subject-centred approach to medicine in the form of psychotherapy, orientated towards psychoanalysis, Mitscherlich continued to analyse the state of training and research for this approach. He argued that adequate facilities for research, therapy, and psychotherapeutic training required interdisciplinary co-operation and could be realized only in the form of a university institute. Since "psychological approaches have proved to be of great importance not only for medicine, but also for pedagogy and sociology", and non-medical psychotherapists had in the past been successful "in the treatment of the great neuroses, and in social psychology, e.g. in the context of child guidance, and educational matters", he proposed also that those not medically qualified academics, such as psychologists or sociologists, should be trained as psychoanalysts in the new institute.

In the concluding sections of the Memorandum, Mitscherlich attempted to delineate the area of future activities and competence of the new institute against that of the already existing psychiatric department, and to dismiss any potential claims of the faculty's chair of psychiatry, Professor Kurt Schneider, to the field of psychotherapy. For this, he pointed to the fact that German academic psychiatry had for decades rejected and devalued depthpsychology, that it had concentrated on a psychology of conscience and on a purely descriptive approach to the pathological phenomena of the psyche, where it had barely addressed the psychological dimension at all.

In summary, the purpose of Mitscherlich's proposal for a new institute or academic programme was not to promote psychotherapy in the narrow sense as a method for minor or "neurotic" psychological disorders, but to produce a fundamental revision of the theoretical and methodological repertoire of medicine in general. With this broad scope, the Memorandum directly converged with the main thrust of the critique and reformation of somaticscientific medicine formulated in the previous debates on the "crisis of medicine". In contrast to already existing or earlier institutions for psychotherapeutic training and therapy, Mitscherlich argued for a university setting to link psychoanalytical psychotherapy to all other medical specialities and, at the same time, to open it up to the behavioural sciences. Treatment and training should be systematically linked to interdisciplinary research and to an equally systematic exchange with as many other academic disciplines as possible.

Mitscherlich's proposal was supported by Weizsäcker who had returned from Breslau in 1945 and had been appointed to a new academic chair for "general clinical medicine" (Allgemeine Klinische Medizin) at the Heidelberg faculty. At the same time that Mitscherlich's Memorandum was produced, Weizsäcker submitted a proposal to the Ministry for Education and Cultural Affairs on the programme and profile of his own department. He intended to give Mitscherlich a position where he could develop and teach his ideas on the theory and philosophy of medicine, and on mind-body interrelationships. In his proposal, Weizsäcker suggested a tripartite structure for his department: he himself intended to focus on basic research in psychophysiology; Mitscherlich was 


\section{Volker Roelcke}

supposed to direct the two other sections of psychotherapy (again in a broad sense) and an "advisory centre for social medicine" (sozialmedizinische Beratungsstelle). ${ }^{33}$

At this point the two stories link up. Probably on the same day that Mitscherlich presented his Memorandum to the dean of the medical faculty, he responded positively to Rektor Bauer's request that he join the new De-nazification Committee. Certainly, this was no accident, rather a strategic move. Mitscherlich knew very well the precarious situation of Bauer and other leading figures in the university, and that he himself, as a known opponent of the former regime, would represent a very welcome figurehead. In effect, he used his positive political reputation to increase the chances for the establishment of the psychotherapeutic institute. This configuration is paradigmatic in that it exemplifies the persistent scepticism towards and indeed virtual rejection of psychoanalysis by German psychiatrists, and - in a broader perspective - the lack of interest in any kind of systematized psychotherapeutic approach to psychiatric, or somatic disorders. It also shows that the success of postwar psychotherapy and psychosomatic medicine in and outside German universities was not a consequence of an acceptance by physicians of the merits of psychoanalysis, or psychotherapy, but the result of outside political pressures.

What happened to Mitscherlich's initiative? The following events may be understood as reactions to three features of Mitscherlich's proposal: namely, his claim to a very broad understanding of "psychotherapy" based on psychoanalysis and targeted at medicine in general; his additional claim to an open, inter-faculty approach and sphere of competence of the new programme; and the fact that his academic and public status was closely linked with the political situation at the time.

A vehement protest at Mitscherlich's proposal was formulated by the head of the psychiatric department, Professor Kurt Schneider. Schneider's objections may be summarized in two central arguments: first, he feared that the sphere of competence of his department would be reduced to that of a "pure lunatic asylum" (reine Irrenklinik). The realm of neurology — in many medical schools traditionally covered by the psychiatric departmenthad already been appropriated by a newly created neurological section within the department of internal medicine. The proposed new institute would now further diminish his sphere of competence by taking away his powers and responsibility for the diagnosis and therapy of "psychogenic states". Second, he formulated an extensive polemic against psychoanalysis. Drawing on the long tradition of such polemics, he diagnosed psychoanalysis as an "aberration" (Verirrung), and as "fanciful speculation and construction" (Phantasie und Konstruktion). ${ }^{34}$

Following Schneider's strong rejection of Mitscherlich's proposal, a heated debate evolved in the faculty, focusing on the importance or impact of psychoanalysis for medicine and for the university. Apart from Weizsäcker, Mitscherlich had two further allies, the professor of internal medicine, Curt Oehme, and the neurologist Paul Vogel. ${ }^{35}$ Mitscherlich's supporters repeatedly argued that compensation was due to Jewish

\footnotetext{
${ }^{33}$ Weizsäcker's proposal of 25 May 1946, is located in AMA, rep. II a 1; There is an earlier version in UA HD PA Mit., letter from Weizsäcker, dated 4 April 1946.
}

\footnotetext{
${ }^{34}$ UA HD, PA Mit., letter from Schneider, dated 13 June 1946.

${ }^{35}$ See AMA rep. II a 1, statement by Oehme (dated 8 June 1946); and UA PA Mit., statement by Vogel (dated 8 July 1946).
} 


\section{Psychotherapy in Germany, c. 1945-1992}

physicians for the injustices done to them and to psychoanalysis during the Nazi period. ${ }^{36}$ Finally, in a skilful move, Schneider argued that psychoanalysis - as promoted by Mitscherlich—had pretensions well beyond medicine reaching far into the spheres of "psychology, paedagogics, criminology, the arts, and religious studies", and that therefore, the medical faculty could not take a decision on the proposal. ${ }^{37}$ The dean could not see how to resolve the conflict and followed Schneider's suggestion to pass the problem on to the higher authorities of the university, thus involving the senate and the Rektor in the decision. Bauer, as Rektor, asked the eminent philosopher Karl Jaspers and the professor of law Gustav Radbruch for an official opinion. After graduating in medicine, Jaspers had been trained as a clinical psychiatrist and had published a fundamental work on the theory and methodology of psychiatry (Allgemeine Psychopathologie, 1913) before he turned to psychology and philosophy, of which he was appointed professor in 1916. His publications also served as a point of reference for the later tradition of phenomenological psychiatry. ${ }^{38}$

In his statement, Jaspers separated the issue of an appropriate field of activity for Mitscherlich from the question about the necessity and status of an institute for psychotherapy. Regarding Mitscherlich, Jaspers pointed to the younger colleague's personal qualities, his "high intellectual rank" and "comprehensive and thorough culture" (umfassende Bildung), and concluded that it was imperative for the university to create an adequate position in academic teaching and research for him.

For this judgement to be fully understood, it should be noted that in 1937, Jaspers himself was forced to resign from his chair in philosophy because of his wife's Jewish family background, and that Mitscherlich and Jaspers had been in regular exchange during the war on medical, philosophical and political questions. After the war, Jaspers had joined forces with Bauer to promote the re-opening of the university and, in the context of these activities, had repeatedly stressed the need for a critical analysis of the previous twelve years. ${ }^{39}$

In the second part of his statement, Jaspers formulated a massive critique of psychoanalysis. He argued that:

... as far as one can judge today, psychoanalysis is mainly the expression of an ideology (Weltanschauung) ... Based merely on this ... the establishment of an institute would perhaps be a fateful step for the purity and vigour of the academic spirit at the university ... The phenomenon itself is fraught with dangers which, once realized, will be difficult to master. Things lacking all basis, things magical and uncritical can easily take hold of many of our youth whose ability to think, after twelve years of educational neglect, has reached a nadir. As soon as psychoanalysis, in its present state, becomes a discipline, represented by psychoanalysts who have no other medical training, then there would emerge a whole stream of nonsensical popular psychoanalytical literature ... Freud ... from both an academic and a moral point of view, is not the kind of figure who could sustain a discipline or new type of institute. ${ }^{40}$

\footnotetext{
${ }^{36}$ For example, UA HD, Personalakte v. Weizsäcker, letter to the dean, Engelking, dated 25 May 1946.

${ }^{37}$ Ibid., letter from Schneider, 21 June 1946.

${ }^{38}$ On Jaspers and his contributions to psychiatry, see Matthias Bormuth, Lebensführung in der Moderne: Karl Jaspers und die
}

Psychoanalyse, Stuttgart, Fromann Holzboog, 2002.

${ }^{39}$ On Jaspers' political engagement, and his relationship with Bauer and Mitscherlich, see de Rosa, op. cit., note 20 above; and Bormuth, op. cit., note 38 above, pp. 197-232.

${ }^{40}$ AMA, rep. II a 1 , statement by Jaspers dated 14 July 1946. 


\section{Volker Roelcke}

In conclusion, Jaspers stated that Mitscherlich deserved a forum for his psychotherapeutic work, but that this should be integrated into an already existing academic institution: "Attaching him to the psychiatric department would seem to be the most productive option, simply because of the difficulties to be overcome". The decision about the founding of an independent institute for psychotherapy should be postponed and made dependent on the probation of Mitscherlich's psychoanalytic programme: "Confidence will only be earned when those putting psychoanalysis into practice prove its sobriety, clarity, and medical and scientific reliability, and, in doing so, ensure beyond any doubt that it [psychoanalysis] is restricted to the genuine medical task of therapy." 41

Thus, Jaspers' position can be summarized as follows: first, psychoanalysis does not have the qualities of a proper science (Wissenschaft), but is rather an ideology (Weltanschauung) which should not be made the basis for an academic institution. Second, a programme in psychotherapy should be established not because of the potential value of the theories and methods of depth psychology, but as a concession to Mitscherlich. And third, psychotherapy should be practised under the control of a well-tried and reliable medical institution, and should be evaluated according to the terms and standards of medicine.

Radbruch, the second referee, followed in his statement the recommendations of Jaspers without qualification. ${ }^{42}$ In August 1946, the Rektor officially wrote to the dean of the medical faculty that the senate had unanimously agreed on the invited statements and recommended that the faculty should accept Jaspers' proposals. ${ }^{43}$ The faculty, in turn, followed this recommendation, however with the slight, but decisive, modification that the new programme should not be located in the psychiatric department, but attached to Weizsäcker's section within the department of internal medicine, to avoid potentially lasting conflicts. The decision about a separate budget and separate rooms should be taken at a later, unspecified, date. ${ }^{44}$

During the following three years, Mitscherlich repeatedly attempted to clarify the organizational conditions for the psychotherapeutic unit and to get access to the promised financial resources, but did not succeed. His prominent connection with the Nuremberg medical trial made him widely unpopular, in particular among senior academic physicians, many of whom claimed that he was an example of someone who fouled his own nest. ${ }^{45}$

For a number of semesters he went on leave for psychoanalytic training and research in Basel and Zurich, and since the faculty was not prepared to implement the promised programme, he threatened several times to leave Heidelberg definitively. ${ }^{46}$ Two events led to a decisive change in late 1948. The prominent lawyer and politician Carlo Schmid, a leading figure in the post-war Social Democratic Party and member of the parliamentary council which drafted the new constitution (Grundgesetz) for the Federal Republic was approached by Mitscherlich and contacted the Rektor of the university. He formulated a strong plea that the university should undertake everything possible to keep Mitscherlich at

\footnotetext{
${ }^{41}$ Ibid.

${ }^{42}$ UA HD PA Mit.

${ }^{43}$ UA HD PA Mit., letter dated 2 Aug. 1946.

${ }^{44}$ Ibid., letter dated 21 Oct. 1946.

${ }^{45}$ On the debates and accusations surrounding Mitscherlich's documentation of the Nuremberg
}

medical trial, see Jürgen Peter, Der Nürnberger Ärteprozess im Spiegel seiner Aufarbeitung anhand der drei Dokumentensammlungen von Alexander Mitscherlich und Fred Mielke, Münster,

LIT, 1994; and Weindling, op. cit., note 28 above. ${ }^{46}$ UA PA Mit., various letters to the dean, medical faculty. 
Heidelberg. Again, as in Jaspers' statement, the foremost argument in favour of this was not related to psychotherapy, i.e. its potential benefits for suffering patients, but to politics. Schmid wrote: "I do not want to miss the chance to point out that Dr Mitscherlich is one of the few academic teachers who were imprisoned for their political attitudes during the 'Third Reich'", ${ }^{47}$ In private circles, Schmid also expressed his sympathies with Mitscherlich's role in documenting the atrocities of Nazi physicians and his attempts to analyse the causes and consequences of Nazi medicine. ${ }^{48}$

Immediately after the Rektor received the letter, the situation changed. The budget for the programme was made available. Mitscherlich returned to Heidelberg to take up teaching in the summer of 1949, an assistant was appointed, and he was promised that the rooms he required would be made available from the following year. In addition, Mitscherlich and Weizsäcker were able to convince the Rockefeller Foundation to fund their project- the only medical project supported by the Foundation's Medical Sciences Division after the war. ${ }^{49}$ With these financial resources from abroad granted on the condition that the university would contribute its own share, the long envisaged programme could finally become a reality.

Alan Gregg, director of the Medical Sciences Division, had during a tour of Europe also visited Heidelberg. In September 1949, he met Weizsäcker and Mitscherlich, and noted in his diary that he had a "first rate impression of both". ${ }^{50}$ The correspondence between Gregg and the European representative of the Foundation, R R Struthers, testifies to the high esteem in which they both held Mitscherlich and his project. In the proposal which Gregg and Struthers presented to the Board of Trustees of the Foundation, they first of all outlined the general context of the psychotherapeutic project in post-war Germany from their perspective. Their initial views were given in more detail in a later proposal.

Admittedly the large problem of interpersonal relationships and attitude is fundamental to the problem of Germany with its tradition of rigid authoritarianism of the social organization and lack of sense of individual responsibility. It is obvious that The Rockefeller Foundation is able to influence only a very small facet of this problem. In the present instance, assistance to the development of an Institute for Psychosomatic Medicine [... may be expected to act] as a stimulus to the development of a more humanistic pattern in the treatment of the sick and in medical education. $^{51}$

The proposal listed the following functions of the new institute:

To provide an outpatient clinic for psychosomatic disease and psychoneuroses, together with a small inpatient department (ten beds) for exploration and treatment of cases sent by outside clinics;

To develop research in psychosomatic medicine, including psychoneuroses and psychological aspects of social medicine;

To serve as a psychoanalytic training centre;

To develop the field of psychological tests.

${ }^{47}$ UA HD PA Mit., letter from Schmid, dated 28 Dec. 1948.

${ }^{48}$ Ulrich Ehebald, private communication to the author, June 2000.

${ }^{49}$ Rockefeller Archive Center, Tarrytown, NY, Rockefeller Foundation 717 A, R.G.
1.2, Box 5, f. 53, Alan Gregg diary,

19 Sept. 1949.

${ }^{50}$ Ibid.

${ }^{51}$ Ibid., motion of 19 June 1953 to continue support for Mitscherlich's department; this later motion summarizes their earlier views. 


\section{Volker Roelcke}

The Executive Committee of the Foundation fully accepted the proposal in January 1950, and granted three years' support with the sum of $\$ 51,000$, or DM $232,800 .^{52}$

Additional financial resources were approved by the state of Baden (DM 130,000), the university (DM 61,000), and the Chamber of West German Physicians (Ärztekammer, DM 21,500). With these sources of funding and the unanimous support of the university, the Department of Psychosomatic Medicine (Abteilung für psychosomatische Medizin) was finally opened on 15 April $1950 .{ }^{53}$ However, Mitscherlich's proposal to include staff of other disciplines, such as psychologists and sociologists, did not materialize.

\section{Finances, Politics, and Services}

The further development of German psychotherapy since the early 1950s can be interpreted as an extension of the configuration of resources and conflicts that characterized the Heidelberg case. The strong theoretical orientation towards psychoanalysis (or to a lesser degree holistic approaches), an institutionalization that was completely separate from, and in confrontation with psychiatry, the recruitment of personnel from somatic medicine (in particular internal medicine and neurology) and the decisive impact of external political and economic factors can all be identified as core features of these developments. The following account will use the "landmark" events between the late 1940s and the early 1990s as identified by Annemarie Dührssen and other representatives of the discipline to illustrate the prominence of these features. ${ }^{54}$

The impact of finance is documented by the success of the institutionalized association between psychotherapeutic programmes and social insurance originating from a Berlin model. Immediately after the end of the war in May 1945, the former German Institute for Psychological Research and Psychotherapy was re-founded as Institut für Psychopathologie und Psychotherapie, under the same directorship (Harald SchultzHencke, and Werner Kemper). ${ }^{55}$ After negotiations with the Versicherungsanstalt Berlin, the central institution of Berlin's post-war social insurance, a contract was

\footnotetext{
${ }^{52}$ Ibid., letter to Prof. Freudenberg, Rector, 20 Jan. 1950.

${ }^{53}$ Ibid., letter from Mitscherlich to Gregg, 29 June 1950.

${ }^{54}$ Dührssen, op. cit., note 1 above; HorstEberhard Richter, Die Chance des Gewissens. Erinnerungen und Assoziationen, Hamburg, Hoffmann \& Campe, 1986, pp. 150-92; Adolf-Ernst Meyer, 'Eine kurze Geschichte der Psychosomatik. Der Sonderweg der ehemaligen Bundesrepublik', in Th von Uexküll (ed.), Integrierte Psychosomatische Medizin in Praxis und Klinik, 2nd ed., Stuttgart, Schattauer, 1992, pp. 35-42; Benedikt Waldherr, 'Geschichte der Psychotherapie. Ein Vierteljahrhundert bis zum Psychotherapeutengesetz', Bayerisches Ärzteblatt, 2003, 3: $150-1$.

${ }^{55}$ This may appear as remarkable, but is only one of many cases where professionals with or without
}

\begin{abstract}
Nazi party-membership, who had made their arrangements with the regime were quickly re-appointed to their former or similar positions, in order to get the respective institutions functioning; see, for example, for health institutions in Berlin, Udo Schagen, and Sabine Schleiermacher, 'Gesundheitswesen und Sicherung bei Krankheit und im Pflegefall. Einleitung: Rahmenbedingungen für die Reorganisation des Gesundheitswesens. Die Sowjetische Besatzungszone und Berlin', in Bundesministerium fuer Arbeit und Sozialordnung, Bundesarchiv (eds), Geschichte der Sozialpolitik in Deutschland seit 1945, vol. 2/1: 1945-1949. Die Zeit der Besatzungszonen, Baden-Baden, Nomos, pp. 464-528, on p. 525-6. For the specific case of Kemper, see Hans Füchtner, 'Psychoanalytiker, Mitläufer, Nazi, Gestapomann, militanter Marxist? Der Fall Werner Kemper', Jahrbuch der Psychoanalyse, 2003, 46: 137-91.
\end{abstract}




\section{Psychotherapy in Germany, c. 1945-1992}

signed in April 1946 under which the psychotherapeutic institute would be integrated into the Versicherungsanstalt to provide free psychotherapeutic services for those insured under the statues of the institution. ${ }^{56}$ The Versicherungsanstalt had been created in July 1945 under the auspices of the allied administration of Berlin, and was intended to function as a single insurance cover for 100 per cent of the population-following a political programme not unusual at the time, when the Beveridge plan was on the agenda of the Labour government in the United Kingdom, and France had a popular front government of socialists and communists debating similar schemes. The central motivation to provide insurance cover for psychotherapeutic services was twofold: on a general, political level the aim was to increase the supply of social services offered to the general population (and thus also to increase support for the insurance scheme); a further, more specific intention was to provide preventive and therapeutic services to enable those insured to contribute to rebuilding the economy. ${ }^{57}$

In the new alliance with the Versicherungsanstalt, the Institute was renamed as Zentralinstitut für psychogene Erkrankungen (Central Institute for Psychogenetic Disorders). One of its core activities was to prove the cost-efficiency of systematic psychotherapy for certain groups of patients in order to justify the provision of psychotherapeutic and, in particular, psychoanalytic services. In the early 1950s, Ernst Schellenberg, chairman of the Versicherungsanstalt, as well as being a member of the Social Democratic Party (SPD) and their expert advisor in matters of social policies, suggested to representatives of the Institute an evaluation of the financial input and long-term effects of the psychotherapeutic interventions on offer. If this evaluation turned out to be positive, it might result in these services being made available to all health insurance companies in the Federal Republic. For this purpose, a systematic long-term study of more than 1,000 patients, paid for by the Berlin Allgemeine Ortskrankenkasse (AOK, a successor of the Versicherungsanstalt) was initiated in the mid-1950s to follow up the health status of several hundred individuals whose psychoanalytic treatment had been completed five and ten years previously. The positive results were published in the mid-1960s ${ }^{58}$ and thus analytical psychotherapy was incorporated into the statutory health insurance throughout the Federal Republic of Germany-despite the persistent protests and counter-arguments of leading academic psychiatrists such as Professors Kurt Schneider (Heidelberg), Gottfried Ewald (Göttingen) and Kurt Kolle (Munich). As a consequence, from 1967 psychoanalytical psychotherapy was, in principle, accessible to more than 80 per cent of the German population. The prerequisite was that a medically trained psychotherapist would formulate the indication. The actual therapy might then be carried through either by medical or psychological psychotherapists. As early as 1957, as a consequence of public debates and law suits on the acknowledgment of psychological trauma suffered

\footnotetext{
${ }^{56}$ Annemarie Dührssen, 'Zum 25-jährigen Bestehen des Instituts für psychogene Erkrankungen der Allgemeinen Ortskrankenkasse Berlin', Zeitschrift für Psychosomatische Medizin und Psychoanalyse, 1971, 17: 21-41.

${ }^{57}$ Schagen and Schleiermacher, op. cit., note 55 above, pp. 523-5.
}

\footnotetext{
${ }^{58}$ Annemarie Dührssen, 'Katamnestische Untersuchungen zur Gruppentherapie', Zeitschrift für psychosomatische Medizin, 1963,9: 120-6; Annemarie Dührssen and E Jorswieck, 'Eine empirisch-statistische Untersuchung zur Leistungsfähigkeit psychoanalytischer Behandlung', Nervenarzt, 1965, 36: $166-9$.
} 


\section{Volker Roelcke}

during the Second World War, and the state's obligation to pay for adequate medical therapies, the General Assembly of German Physicians (Deutscher Ärztetag) had introduced a formal qualification (Zusatztitel) in psychotherapy (as, for example, in cardiology) which was bound to a standardized training in the subject approved by the regional chambers of physicians (Ärztekammern), and led to the establishment of psychotherapeutic training institutes all over Germany. ${ }^{59}$ Again, the driving force behind these developments had more to do with political and monetary pressures, than with an acknowledgement by the medical profession and, in particular, psychiatrists of the need for psychotherapeutic approaches and services in the broader field of mental health care.

There was, however, a striking gap between the demand for these newly available services and the, as yet, small number of academic teaching and postgraduate training facilities. This changed as a result of social protests and especially the student movements in the late 1960s. One of the responses of the official political institutions was to reorganize the universities in general, with repercussions also for the structure and content of academic curricula. Under federal legislation, in 1970 a new medical curriculum was put into practice which made "psychotherapy and psychosomatic medicine" an obligatory part of medical teaching all over Germany. As a consequence of this mandatory education, corresponding chairs and departments had to be set up at all of the twenty-three German medical schools. This was perceived as an enormous gain in prestige for the new discipline and resulted in a boom of activities amongst young researchers and academic instructors, and a rapid growth of the number of new trainees in psychotherapy. Inspired by co-operation with neighbouring disciplines in both psychology and somatic medicine, a broad gamut of new approaches were integrated into the therapeutic repertoire and also became the focus of systematic research endeavours, amongst them Gestalt therapy, family therapy, psychodrama, functional relaxation, various forms of movement therapies (for example, konzentrative Bewegungstherapie), as well as music therapy. Psychoanalysis, however, remained the main theoretical paradigm. The university departments were usually linked to an inpatient clinic with newly conceptualized treatment schemes. Further, since it turned out that many patients who presented to the ambulant services had already developed chronic "functional" or psychosomatic conditions-due amongst other things to the previous lack of qualified psychotherapists - the newly available resources and favourable political moves in the 1970s and early 1980s led to the establishment of a considerable number of psychosomatic rehabilitation hospitals. The recommendations of the Psychiatrie-Enquete were one of the major contributing political factors. The Enquete was a systematic inquiry into the state of German psychiatry and mental health care initiated in the late 1960s by various groups, among them academic consultants associated with the tradition of anthropologische Psychiatrie, ${ }^{60}$ as well as the newly

\footnotetext{
${ }^{59}$ See, for example, Svenja Goltermann, 'Psychisches Leid und herrschende Lehre: Der Wissenschaftswandel in der westdeutschen Psychiatrie der Nachkriegszeit', in B Weisbrod (ed.), Akademische Vergangenheitspolitik: Beiträge zur

Wissenschaftskultur der Nachkriegszeit, Göttingen,
}

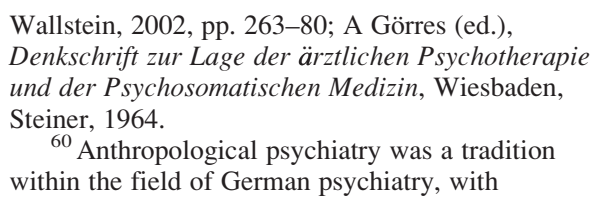


formed German Association for Social Psychiatry (Deutsche Gesellschaft fuer Sozialpsychiatrie), and commissioned by the German federal parliament (Bundestag). Psychotherapists, however, were not among those who initiated the move for the Enquete, since they worked with a different clientele than psychiatrists proper, and not in those institutional settings (state psychiatric hospitals (Landeskrankenhäuser) the former asylums) where a deplorable state of affairs called for change.

The final report of this inquiry was published in 1975. Among many other points regarding asylums in particular and the introduction of psychiatric departments in general hospitals, the report recommended further steps to establish psychotherapeutic services in the community, integrated with inpatient and outpatient services associated with psychotherapeutic departments and hospitals. ${ }^{61}$ The already existing "division of labour" between psychiatry on the one hand and psychosomatic medicine and psychotherapy on the other was accepted continued.

The general situation of psychotherapeutic services, as well as that of teaching and research facilities in the late 1980s is documented in two detailed reports commissioned by the Association of Physicians connected with the statutory health insurance companies (Kassenärztliche Vereinigung) and the German Association for Psychotherapy, Psychosomatic Medicine and Depth Psychology (Deutsche Gesellschaft für Psychotherapie, Psychosomatische Medizin und Tiefenpsychologie, DGPT) founded in 1949. The findings may be summarized as follows.

By 1990, there existed approximately 8,300 beds in psychotherapeutic inpatient institutions, as opposed to around 500 beds in 1950. Some 1,200 of these beds were reserved for acute conditions and provided by university or municipal hospitals; the remaining 7,000 or so beds were located in rehabilitation hospitals, i.e., they were designated for chronic patients. ${ }^{62}$ Most of the latter were funded by old-age pension insurances, as a preventive measure to allow those of pre-pensionable age to work. Apart from the university departments, there existed twenty-seven training institutes for psychoanalytic psychotherapy, which represented about 1,500 psychotherapists, both qualified and in training. ${ }^{63}$ About 52 per cent of them had previously studied medicine, 41 per cent psychology, and 7 per cent had graduated in other fields, such as paedagogics, sociology, theology, or social work. ${ }^{64}$

almost no links (apart from one or two exceptions, for example, in Würzburg) to the newly institutionalized field of psychotherapy/ psychosomatic medicine.

${ }^{61}$ Bericht über die Lage der Psychiatrie in der Bundesrepublik Deutschland: zur psychiatrischen und psychotherapeutisch-psychosomatischen

Versorgung der Bevölkerung, Verhandlungen des Deutschen Bundestags, Drucksache 7/4200, Bonn, Bad Godesberg, Heger, 1975; for psychotherapeutic services in particular, see Manfred Bauer, 'Psychotherapeutische Versorgung', in M Blohmke, Ch v. Faerber, et al. (eds), Handbuch der Sozialmedizin, vol. 3, Stuttgart, Ferdinand Enke, 1976, pp. 275-316. On the developments leading to the Enquete, see, for example, the chapters by Caspar Kulenkampff, Manfred Bauer, and others in
U Hoffmann-Richter, H Haselbeck, R Engfer (eds), Sozialpsychiatrie vor der Enquete, Bonn, Psychiatrie Verlag, 1997.

${ }^{62}$ E Schach, F W Schwartz, H E Kerek-Bodden (eds), Die EvaS-Studie: Erhebung über die Versorgung im ambulanten Sektor, Cologne, Deutscher Ärzteverlag, 1989.

${ }^{63}$ The following numbers are taken from Psychoanalytische Tätigkeit in der Bundesrepublik Deutschland. Ergebnisse einer empirischen Studie im Auftrag der Deutschen Gesellschaft für Psychotherapie, Psychosomatik und Tiefenpsychologie - Praxisstudie, edited by Rudolf Schmid, in co-operation with Heinz Jaschke, et al., Cologne, Prognos 1987.

${ }^{64}$ Due to the pressure from the medical profession, since 1974 the formal status of 


\section{Volker Roelcke}

Seventy per cent of these practising psychotherapists worked in their own practices, 30 per cent were employed by various kinds of hospitals, training institutes, or public institutions. As regards the patients, in 1986 about 33,200 individuals received insurance paid psychoanalytic psychotherapy. About half of these attended the services on their own initiative, whereas the other 50 per cent had been transferred from single-handed practices (from other psychotherapists, psychiatrists, or representatives of somatic medicine), or were in-patients sent from all medical disciplines. Significantly, around 90 per cent were between eighteen and fifty years of age; 58 per cent belonged to the middle or upper social strata.

In addition to these psychoanalytically orientated psychotherapeutic services, behaviour therapy developed as an alternative approach from the 1970s. Remarkably, this tradition was initially mainly employed for the treatment of chronic psychiatric patients, and in the context of state psychiatric institutions, which started to register psychologists for this purpose. From 1980, behaviour therapy was accepted as another mode of psychotherapy by the statutory health insurance companies, since they realized that the existing demand for psychotherapeutic treatment could not possibly be met by the available psychoanalytic services. At that time, some of the insurance companies, which were by law united under the statutory system, decided to refund psychological psychotherapists directly for their treatment, thus bypassing the legally required delegation by physicians. This opened up new possibilities for psychologists, many of whom had studied, or been trained in institutional contexts that were not dominated as much by psychoanalysts as those in medical institutions. The effect was a strong increase in the number of behaviour therapists settled in private practice, and a rapidly growing impact of the behaviourist approach in professional politics. This latter development was reinforced by psychiatrists who considered behaviourist approaches and the concomitant modes of proving efficacy by the qualification and statistical analysis of emotional and cognitive states to be more appropriate for their clientele. The long standing conflicts and mutual hostility between psychoanalysts and psychiatrists were no longer an issue in this new constellation.

A decisive change in the general status of psychotherapy and in the relation between psychotherapy and psychiatry occurred in the wake of the political break in 1989 and the unification of Germany. Since in the German Democratic Republic there existed a different structure of postgraduate medical specialization to that in the Federal Republic, with corresponding formal qualifications, it was necessary to negotiate the merging of the two systems and the structure of the future forms of medical specialization. The previous existence of a broad specialization in psychotherapy in the east (Facharzt für Psychotherapie, comparable to the specialization in internal medicine, Facharzt für Innere Medizin) thus converged with the increased ambitions and inroads of psychiatrists into the field of psychotherapy and led to the delimitation of two "new" specializations during the General Assembly of German Physicians in 1992: the Facharzt für Psychiatrie und Psychotherapie, and the Facharzt für

"psychotherapist" (which was a prerequisite for participation in health insurance paid services) was open only to graduates in medicine and psychology. 


\section{Psychotherapy in Germany, c. 1945-1992}

Psychotherapeutische Medizin. The former was focused on the competences needed in the field of psychiatric disorders, understood in a broad sense, whereas the latter was intended to focus on "functional", and somatoform disorders, including the psychological aspects of somatic disease. On a conceptual level, both psychoanalytical and behaviourist approaches were accepted as efficacious and as forming the basis for any theoretical and practical training. New curricula and standards for the two specializations were formulated by the Assembly, and led to the reorganization of the major professional associations, with the formation of the new and integrated Deutsche Gesellschaft für Psychotherapeutische Medizin in 1993, and the inclusion of "psychotherapy" in the renamed Deutsche Gesellschaft für Psychiatrie, Psychotherapie und Nervenheilkunde. As a consequence of these developments, and also of cut-backs in the budgets of medical schools in general, ${ }^{65}$ in many cases the former departments of "psychosomatic medicine and psychotherapy" were integrated in existing psychiatric departments and the associated hospitals.

\section{Conclusion}

The developments described above illustrate that the core feature of post-Second World War German psychotherapy was an institutionalization completely separate from psychiatry. The newly established medical discipline of "psychosomatic medicine and psychotherapy" comprised academic programmes at medical schools, professional associations and training institutes, as well as a rapidly growing number of sanatoria or rehabilitation hospitals, and psychotherapeutic services provided by single-handed practices which since the mid-1960s were all funded by the statutory health insurance companies or old-age pension schemes.

The emergence of the new field after 1945 may in a number of respects be understood as a primarily politically motivated answer to preceding developments and events. Amongst them, the debates about the "crisis of scientific medicine" during the Weimar republic, the biologistic reductionism and ensuing atrocities of Nazi medicine and the forced migration of Jewish physicians and psychoanalysts were the foremost factors which made such an answer seem plausible and even necessary in the completely new contexts after the end of the war and the breakdown of the former political system. The political willingness to compensate for apparent shortcomings and excesses of German medicine in the preceding period converged with the long standing resistance of German psychiatrists to the introduction of psychoanalytically inspired concepts and practices to mental health care and research. As a result, a number of local initiatives to establish independent psychoanalytically orientated psychotherapeutic programmes fell on fertile ground. The establishment of the Department for Psychosomatic Medicine at the University of Heidelberg illustrates in an exemplary fashion the impact of all these factors, and for almost four decades it served as a model

\footnotetext{
${ }^{65}$ These cuts in public spending, for example, for universities, occurred again in the wake of German unification, and the consequent transfer of considerable
}

funds to the eastern parts of Germany to rebuild public infrastructures. 


\section{Volker Roelcke}

for similar programmes elsewhere. Another major political change in 1989 and new criteria for distributing public funds caused a fundamental reconfiguration of the field from the early 1990s. With this, the broad split between psychiatry and psychotherapy on the levels of concepts, services and academic activities came to an end-a rift which had been the product of the medical and political history of twentieth-century Germany. 